\title{
Effect of Brown Algae Extract Sargassum sp on Malondialdehyde Levels in White Rats (Rattus Norvegicus) Pregnant Wistar Strains
}

\author{
Dahniar ${ }^{1}$, Suryani As'ad ${ }^{2}$, Nasrudin A.Mappeware ${ }^{3}$, Gemini Alam ${ }^{4}$, Budu$^{5}$, Rosdiana Natzir 6 , \\ Burhanuddin Bahar ${ }^{7}$ \\ ${ }^{1}$ Postgraduate Doctoral Program, Faculty of Medicine, Universitas Hasanuddin, ${ }^{2}$ Department of Clinical \\ Nutrition, Faculty of Medicine, Universitas Hasanuddin, ${ }^{3}$ Faculty of Medicine, Universitas Muslim Indonesia, \\ ${ }^{4}$ Faculty of Pharmacy, Universitas Hasanuddin, ${ }^{5}$ Faculty of Medicine, Universitas Hasanuddin, ${ }^{6}$ Department of \\ Biochemistry, Faculty of Medicine, Universitas Hasanuddin, ${ }^{7}$ Faculty of Public Health, Universitas Hasanuddin.
}

\begin{abstract}
Pregnancy is an inflammatory condition that produces unstable oxidative stress and can damage macroeconomic tissue including DNA and protein which disrupt the placentation process. Increased levels of malondialdehyde as an indicator of lipid peroxidation and decreased levels of antioxidants. This research was conducted experimentally with pretest-posttest Control Group Design. Using three treatment groups for the white rat (Rattus Norvegicus) test for Pregnant Wistar Strains. Twenty-one samples consisted of three groups (Group 1 negative control, Group 2: sea algae extract Sargassum sp dose $300 \mathrm{mg} / \mathrm{kg}$ bb/day, Group 3: sea algae extract Sargassum sp dose $600 \mathrm{mg} / \mathrm{kg}$ bb/day. Malondialdehyde levels were determined by examination Eliza sandwich The results showed that Sargassum Sp brown algae extract had a significant effect on decreasing levels of malondialdehyde (300mg p: 0.008 dose; 600mg p: 0.001 dose) in white rats (Rattus norvegicus) Pregnant Wistar Strains.
\end{abstract}

Keywords: Sargassum sp, Malondialdehyde, Rattus norvegicus.

\section{Introduction}

In pregnancy will increase, increase, increase. Oxidative stress that occurs can occur because antioxidants do not compensate. Therefore, under certain conditions triggered by oxidative stress, endogenous antioxidants become insufficient and require exogenous antioxidants to maintain optimal cellular function.

Malondialdehyde (MDA) levels in pregnant women are higher than in nonpregnant women. Increasing MDA levels increase with increasing gestational age from the first, second and third trimesters, in this case, there has been an increase in peroxidation which is a marker (marker) to increase free radicals in the blood ${ }^{1}$. Oxidative stress will disrupt the placentation process. Abnormalities associated with certain diseases for example preeclampsia, mola hydatidosis, and abortion. Increased risk of failure associated with increased free radicals that increase in the development of placental function and effect on the fetus ${ }^{2}$. The increase in oxidative stress corresponds to an increase in lipid peroxidation formation. Oxidative stress will cause damage to trophoblast cells which will start to become abortion (miscarriage).

Reactive oxygen species (ROS) can be obtained endogenously or exogenously but both can affect oocytes and embryos and can also cause oxidative DNA damage which increases the speed of mutagenesis and chromosomal instability ${ }^{3}$. Mitochondrial dysfunction by stress or improper mitochondrial integrity control causes an increase in electron leakage from the respiratory chain. Very reactive superoxide causes itself to be very unstable. This can damage the different macromolecules in the mitochondria including fats, proteins, and DNA that can affect mitochondrial function and stimulate extensive electron leakage and ROS production ${ }^{4}$. 
Brown algae Sargassum sp has the highest antioxidant activity compared to red and green seaweed and the main antioxidant component found in Sargassum sp is a polyphenol compound ${ }^{5}$. Most compounds in the brown algae Sargassum sp are carotenoids which act as antioxidant activities. The ability of polyphenols as antioxidants is based on the presence of hydroxyl groups which are aromatic compounds as contributors to hydrogen atoms for free radicals and the ability of electron delocalization which has a double bond for conjugation, as well as the stability of the resonance structure $^{6}$.

\section{Materials and Method}

This study used a simple randomized design method using three groups of test animals of white rat (Rattus norvegicus) strains of pregnant Wistar and were treated as follows:

a. Negative Control Group (Group 1): mice were only given distilled water on days 7-19 of pregnancy with a frequency of 1 time per day.

b. Treatment group 1 (Group 2): rats were given seaweed extract Sargassum sp on days 7-19 of pregnancy with a dose of $300 \mathrm{mg} / \mathrm{kg}$ rat frequency 1 time per day

c. Treatment group 2 (Group 3): rats were given seaweed extract Sargassum sp on days 7-19 of pregnancy with a dose of $600 \mathrm{mg} / \mathrm{kg}$ rat frequency 1 time per day.

In this study, the sample was adjusted to the inclusion criteria, while the prospective white rat (Rattus norvegicus) strain of female Wistar with a bodyweight of 200-250 grams with age 3-4 months. Female mice were mated with male rats during the estrous phase with a system of one female and one male partner for 24 hours which had previously been examined by vaginal smears to confirm the lust phase of the estrus period(7). The next day the female rat was examined to ensure marriage by checking vaginal smears containing much sperm and examined signs of pregnancy such as signs of plugs (vaginal redness, swelling and thick lumps in the vaginal introitus) which were stated as the first day of pregnancy. The cage is placed at room temperature using 12 hours of bright lighting and 12 hours of darkness, as well as maintaining the humidity of the room. Each rat was given once a day according to the treatment set.
The three groups of test animals, each consisting of seven white rats (Rattus norvegicus) strains of pregnant Wistar, were examined for Malondialdehyde levels on the 7th day of pregnancy as a pre-test examination, and given the intervention of brown algae extract Sargassum sp in both treatment groups according to the dose of treatment predetermined and negative control groups are only given equates once a day. The treatment began on the 7 th day until the 19th day. Furthermore, on the 19th day, the level of malondialdehyde was examined as a post-test.

All conditions and handling of test animals are carried out by following a protocol approved by the medical research ethics committee of the Faculty of Medicine, University of Hasanuddin, number: No.199 / UN4.6.4.5.31 / PP36 / 2019.

Manufacture of Sargassum sp brown algae extract

The tools needed for the manufacture of Sargassum sp brown algae extracts are trash, blender, 30 mesh sieve, scales, stirrer, 1-liter tube, filter paper, Erlenmeyer flask, measuring flask and rotary evaporator, while the material for extracting is Sargassum sp. water, and ethanol 96\%. Sargassum sp brown algae powder which has been mashed in maceration with $96 \%$ ethanol solvent, then allowed to stand for 3 days but still stirring every day. The ethanol extract is then stored in the Ellen Meyer flask to be evaporated with a Rotary vacuum evaporator at $40^{\circ} \mathrm{C}$ to produce a familiar extract (concentrated) with a constant weight.

Measurement of malondialdehyde levels using an enzyme-linked immunosorbent assay (ELISA) sandwich technique.

Prepare all reagents (standard, control) and samples. Prepare a strip well that is conditioned at room temperature for \pm 30 minutes. Add $50 \mu$ of standard solution to well A1-A6. Add $40 \mu 1$ of serum to the well and then add $10 \mu \mathrm{l}$ of anti-MDA antibody to the wells. Add $50 \mu \mathrm{l}$ of streptavidin-HRP each to the sample well and standard well. Cover well with seal. Incubate at $37^{\circ} \mathrm{C}$ for 60 minutes. Remove the seal and wash the plate with buffer washing 5 times. Add $50 \mu$ of substrate A solution to each well then add $50 \mu 1$ of substrate B solution to the well (standard and sample). Cover the plate with a seal. Incubate at $37^{\circ} \mathrm{C}$ for 10 minutes. Add $50 \mu$ stop solution 
into the well (standard and sample), there will be a color change from blue to yellow. Measure the optical density (OD value) of each well using a microplate reader using a wavelength of $450 \mathrm{~nm}$ within 10 minutes after stopping adding solutions.

\section{Results}

a. Malondialdehyde (MDA) levels in white rats (Rattus norvegicus) pre and post-test strains of pregnant women by a group.
MDA levels at the lowest pre-test were found in the negative control group $(0.26 \pm 0.11 \mathrm{nmol} / \mathrm{ml})$ compared to the Sargassum sp extract group with a dose of $300 \mathrm{mg}$ $/ \mathrm{kgBB} /$ day $(0.43 \pm 0.10 \mathrm{nmol} / \mathrm{mL})$ and Sargassum sp extract group dose $600 \mathrm{mg} / \mathrm{kgBB} /$ day $(0.41 \pm 0.07$ $\mathrm{nmol} / \mathrm{mL}$ ). At the post test, the lowest MDA level was found in the Sargassum sp extract group at a dose of 600 $\mathrm{mg} / \mathrm{kgBB} /$ day $(0.25 \pm 0.10)) \mathrm{nmol} / \mathrm{mL})$ compared to the Sargassum sp extract group at a dose of $300 \mathrm{mg}$ $/ \mathrm{kgBB} /$ day $(0,40 \pm 0.12 \mathrm{nmol} / \mathrm{mL})$ and negative control group $(0.41 \pm 0.06 \mathrm{nmol} / \mathrm{mL})$ (Table. 1$)$.

Table 1. Malondialdehyde (MDA) levels in white rats (Rattus norvegicus) Pregnant Wistar Strains Pre and Post Test by Group

\begin{tabular}{|c|c|c|c|c|c|c|c|}
\hline \multirow{3}{*}{ Group } & \multirow{3}{*}{$\mathbf{n}$} & \multicolumn{6}{|c|}{ MDA levels (nmol / mL) } \\
\hline & & \multicolumn{2}{|c|}{ Pre Test } & \multicolumn{2}{|c|}{ Post Test } & \multicolumn{2}{|c|}{ Change } \\
\hline & & $\begin{array}{l}\text { Mean } \\
\text { (SD) }\end{array}$ & $\begin{array}{l}\text { Median (Min- } \\
\text { Max) }\end{array}$ & $\begin{array}{l}\text { Mean } \\
\text { (SD) }\end{array}$ & $\begin{array}{l}\text { Median (Min- } \\
\text { Max) }\end{array}$ & $\begin{array}{l}\text { Mean } \\
\text { (SD) }\end{array}$ & $\begin{array}{l}\text { Median (Min- } \\
\text { Max) }\end{array}$ \\
\hline Negative Control & 7 & $\begin{array}{l}0,26 \\
(0,11)\end{array}$ & $\begin{array}{l}0,27 \\
(0,10-0,38)\end{array}$ & $\begin{array}{l}0,41 \\
(0,06)\end{array}$ & $\begin{array}{l}0,43 \\
(0,28-0,45)\end{array}$ & $\begin{array}{l}0,14 \\
(0,11)\end{array}$ & $\begin{array}{l}0,11 \\
0,03-0,35)\end{array}$ \\
\hline $\begin{array}{l}\text { Sargassum sp } 300 \\
\text { mg dose }\end{array}$ & 7 & $\begin{array}{l}0,43 \\
(0,10)\end{array}$ & $\begin{array}{l}0,45 \\
(0,25-0,60)\end{array}$ & $\begin{array}{l}0,40 \\
(0,12)\end{array}$ & $\begin{array}{l}0,43 \\
(0,15-0,51)\end{array}$ & $\begin{array}{l}-0,03 \\
(0,10)\end{array}$ & $\begin{array}{l}0,02 \\
(-0,1-0,08)\end{array}$ \\
\hline $\begin{array}{l}\text { Sargassum sp } 600 \\
\text { mg dose }\end{array}$ & 7 & $\begin{array}{l}0,41 \\
(0,07)\end{array}$ & $\begin{array}{l}0,41 \\
(0,32-0,50)\end{array}$ & $\begin{array}{l}0,25 \\
(0,10)\end{array}$ & $\begin{array}{l}0,22 \\
(0,11-0,42)\end{array}$ & $\begin{array}{l}-0,15 \\
(0,12)\end{array}$ & $\begin{array}{l}-0,2 \\
(-0,2-0,1)\end{array}$ \\
\hline
\end{tabular}

b. Differences in levels of malondialdehyde (MDA) in white rats (Rattus norvegicus) strains of pre and post-test pregnant Wistar by group

MDA levels in the negative control group increased $0.14 \pm 0.11 \mathrm{nmol} / \mathrm{mL}$ and based on the results of the Pairet T-Test statistic, there was a significant difference in the increase in MDA levels in white rats (Rattus norvegicus) strains of pregnant Wistar between pretest and post-test (p: 0.012). The MDA levels in the Sargassum sp extract group at a dose of $300 \mathrm{mg} / \mathrm{kg} \mathrm{bb} /$ day decreased $0.03 \pm 0.10 \mathrm{nmol} / \mathrm{mL}$. While the MDA levels in the Sargassum sp extract group dose $600 \mathrm{mg} /$ $\mathrm{kg} \mathrm{bb} /$ day there was a decrease of $0.15 \pm 0.12 \mathrm{nmol} / \mathrm{mL}$ and based on the results of the Pairet T-Test statistic it was found that there was a significant difference in the decrease in MDA levels in white rats (Rattus norvegicus) strains of pregnant Wistar between pre-test and post-test (p: 0.019) (table.2) 
Table 2. Differences in levels of Malondialdehyde (MDA) in White Rats

(Rattus norvegicus) Pregnant Wistar Pre and Post Test Strains Based on group

\begin{tabular}{|c|c|c|c|c|c|}
\hline \multirow{3}{*}{ Group } & \multirow{3}{*}{ Time } & \multirow{3}{*}{$\mathbf{N}$} & \multicolumn{2}{|c|}{ MDA levels (nmol / mL) } & \multirow{3}{*}{ p-Value } \\
\hline & & & \multicolumn{2}{|l|}{ Mean (SD) } & \\
\hline & & & Score & Change & \\
\hline Negative Control & $\begin{array}{l}\text { Pre Test } \\
\text { Post Test }\end{array}$ & $\begin{array}{l}7 \\
7\end{array}$ & $\begin{array}{l}0,26(0,11) \\
0,41(0,06)\end{array}$ & $0,14(0,11)$ & 0,012 \\
\hline Sargassum sp $300 \mathrm{mg}$ dose & $\begin{array}{l}\text { Pre Test } \\
\text { Post Test }\end{array}$ & $\begin{array}{l}7 \\
7\end{array}$ & $\begin{array}{l}0,43(0,10) \\
0,40(0,12)\end{array}$ & $-0,03(0,10)$ & 0,425 \\
\hline Sargassum sp $600 \mathrm{mg}$ dose & $\begin{array}{l}\text { Pre Test } \\
\text { Post Test }\end{array}$ & $\begin{array}{l}7 \\
7\end{array}$ & $\begin{array}{l}0,41(0,07) \\
0,25(0,10)\end{array}$ & $-0,15(0,12)$ & 0,019 \\
\hline
\end{tabular}

c. Differences in levels of malondialdehyde (MDA) in white rats (Rattus norvegicus) strains of pregnant Wistar between groups

Based on the results of the Independent statistical test sample t-test, there was a significant difference in changes in MDA levels between the negative control group and the Sargassum sp extract group dose $300 \mathrm{mg} / \mathrm{kg}$ bb/day (p: 0.008), there was a significant difference in changes in MDA levels between the negative control group and the extract group Sargassum sp dose $600 \mathrm{mg} / \mathrm{kg}$ bb/day (p: 0.001), and there was no difference in changes in MDA levels between the Sargassum sp dose $300 \mathrm{mg} / \mathrm{kg}$ bb/day and Sargassum sp extract group dose $600 \mathrm{mg} / \mathrm{kg}$ bb/day (p: 0.072) (table.3)

Table 3. The difference in levels of malondialdehyde (MDA) in White Rats

(Rattus norvegicus) Intergroup Pregnant Wistar Strains

\begin{tabular}{|c|c|c|c|c|}
\hline \multirow{3}{*}{ Group } & \multirow{3}{*}{$\mathbf{n}$} & \multicolumn{2}{|c|}{ Change in MDA levels (nmol / mL) } & \multirow{3}{*}{ p-Value* } \\
\hline & & \multicolumn{2}{|l|}{ Mean (SD) } & \\
\hline & & Score & Change & \\
\hline $\begin{array}{l}\text { Negative Control } \\
\text { Sargassum sp } 300 \mathrm{mg} \text { dose }\end{array}$ & $\begin{array}{l}7 \\
7\end{array}$ & $\begin{array}{l}0,14(0,11) \\
-0,03(0,10)\end{array}$ & $0,18(0,05)$ & 0,008 \\
\hline $\begin{array}{l}\text { Negative Control } \\
\text { Sargassum sp } 600 \text { mg dose }\end{array}$ & $\begin{array}{l}7 \\
7\end{array}$ & $\begin{array}{l}0,14(0,11) \\
-0,15(0,12)\end{array}$ & $0,30(0,06)$ & 0,001 \\
\hline $\begin{array}{l}\text { Sargassum sp } 300 \mathrm{mg} \text { dose } \\
\text { Sargassum sp } 600 \mathrm{mg} \text { dose }\end{array}$ & $\begin{array}{l}7 \\
7\end{array}$ & $\begin{array}{l}-0,03(0,10) \\
-0,15(0,12)\end{array}$ & $0,12(0,06)$ & 0,072 \\
\hline
\end{tabular}




\section{Discussion}

The results of this study found that administration of Sargassum Sp brown algae extract had a significant effect on decreasing levels of malondialdehyde (MDA) in white rats (Rattus norvegicus) strains of pregnant Wistar at a dose of $300 \mathrm{mg} / \mathrm{kg} \mathrm{bb} /$ day (p: 0.008) and a dose of $600 \mathrm{mg} / \mathrm{kg}$ bb/day (p: 0.001) compared to the negative control that had increased. This indicates that the brown algae Sargassum sp at a dose of $300 \mathrm{mg} / \mathrm{kg}$ bb and $600 \mathrm{mg} / \mathrm{kg}$ bb gave a positive effect on the decrease in levels of malondialdehyde in pregnant Wistar strain white rats.

The content of bioactive compounds than brown algae Sargassum sp is a flavonoid compound that directly reacts with free radicals by capturing unpaired electrons to free radicals without producing other free radicals as a result of the reaction ${ }^{8}$. Flavonoids can inhibit initiation by capturing major radicals such as superoxide. The effects of flavonoids on ROS are through two mechanisms by increasing endogenous antioxidants and capturing free radicals or neutralizing free radicals ${ }^{9}$.

The flavonoid groups identified in the Sargassum sp extract are catechins and quercetin ${ }^{10}$. These two groups of flavonoids are thought to have a role to ward off free radicals so that they can reduce levels of malondialdehyde in the white rat group of pregnant Wistar strains that have been treated. Quercetin is a flavonoid compound that has the most powerful antiradical properties against hydroxyl radicals, peroxyl and superoxide anions ${ }^{11}$.Flavonoids protect cells from attack by reactive oxygen compounds such as singlet oxygen, superoxide, peroxyl radicals, hydroxyl radicals, and peroxynitrite. Lipid damage occurs through three phases, namely the initiation, propagation and the termination stage which is the final stage by binding a free radical with other free radicals so that they are no longer reactive ${ }^{12}$. When a hydrogen atom is removed by a molecular lipid some compounds will react with a hydrogen atom that forms hydroxyl radicals $(\bullet \mathrm{OH})$,alkoxy (RO),peroxyl (ROO) and possibly also with $\mathrm{HO} 2$ but not including $\mathrm{H} 2 \mathrm{O} 2$.Membrane lipids are phospholipids consisting of unsaturated fatty acids that facilitate peroxidation due to the presence of hydrogen atoms containing only one electron, in this case, there is a carbon atom without electron pairs. The double bonds in fatty acids will weaken the $\mathrm{CH}$ bonds in carbon atoms adjacent to the double bonds which makes it easy for hydrogen atoms to transfer. Likewise, if there are sufficient oxygen concentration of lipid radicals, it will react with oxygen to form peroxyl radicals $(\mathrm{ROO} \bullet)$, this stage occurs in propagation. For the termination stage, peroxyl radicals (ROO•) will attack other hydrogen atoms originating from other lipid molecules that are close and produce lipid peroxides and peroxyl radicals or interact with other antioxidants. Therefore this process causes the cessation of the oxidation process by neutralizing free radicals that are formed during oxidation.

This study shows that in test animals with control groups there was a significant increase in malondialdehyde levels between pre-test and posttest (p: 0.012). This illustrates that in pregnancy two phenomenological oxidative stress phenomena are found, which occur in the trimester in the peripheral part of the placenta.Therefore there is an increase in local oxygen concentration at a stage of pregnancy so that the trophoblast has a concentration and activity of major or endogenous antioxidants such as superoxide dismutase (SOD) is low ${ }^{13}$. The presence of major trophoblastic oxidative damage and progressive degeneration of the villi will trigger the formation of the fetal membrane which is an important developmental step for vaginal delivery.

\section{Conclusion}

Based on research conducted found Sargassum Sp brown algae extract gives a significant effect on decreasing levels of malondialdehyde (MDA) in white rats (Rattus norvegicus) pregnant Wistar strains at a dose of $300 \mathrm{mg} / \mathrm{kg} \mathrm{bb} /$ day and a dose of $600 \mathrm{mg} / \mathrm{kg} \mathrm{bb} /$ day.

Ethical Clearance- Taken from Medical Faculty ethical committee

\section{Source of Funding- Self}

\section{Conflict of Interest - Nil}

\section{References}

1. Chen Y, Yue R, Zhang B, Li Z, Shui J, Huang X. Effects of probiotics on blood glucose, biomarkers of inflammation and oxidative stress in pregnant women with gestational diabetes mellitus: A metaanalysis of randomized controlled trials. Med Clin 
(Barc). 2020 Mar;154(6):199-206.

2. Harris LK, Benagiano M, D'Elios MM, Brosens I, Benagiano G. Placental bed research: II. Functional and immunological investigations of the placental bed. Am J Obstet Gynecol. 2019 Nov;221(5):45769.

3. Teloni F, Michelena J, Lezaja A, Kilic S, Ambrosi C, Menon S, et al. Efficient Pre-mRNA Cleavage Prevents Replication-Stress-Associated Genome Instability. Mol Cell. 2019 Feb;73(4):670-683.e12.

4. Said RS, Mohamed HA, Kamal MM. Coenzyme Q10 mitigates ionizing radiation-induced testicular damage in rats through inhibition of oxidative stress and mitochondria-mediated apoptotic cell death. Toxicol Appl Pharmacol. 2019 Nov;383:114780.

5. Yuan Y, Zhang J, Fan J, Clark J, Shen P, Li Y, et al. Microwave assisted extraction of phenolic compounds from four economic brown macroalgae species and evaluation of their antioxidant activities and inhibitory effects on $\alpha$-amylase, $\alpha$-glucosidase, pancreatic lipase and tyrosinase. Food Res Int. 2018 Nov;113:288-97.

6. Stepanić V, Matić S, Amić A, Lučić B, Milenković $\mathrm{D}$, Marković Z. Effects of conjugation metabolism on radical scavenging and transport properties of quercetin - In silico study. J Mol Graph Model. 2019 Jan;86:278-85.

7. Miller R. Naloxone inhibits mating and conditioned place preference for an estrous female in male rats soon after castration. Pharmacol Biochem Behav. 1987 Apr;26(4):781-9.

8. B. V, K. S, R. A, K. Usha S, M. A. Bioactive and thermostable sulphated polysaccharide from Sargassum swartzii with drug delivery applications. Int J Biol Macromol. 2020 Jun;153:190-200.

9. Tavsan Z, Kayali HA. Flavonoids showed anticancer effects on the ovarian cancer cells: Involvement of reactive oxygen species, apoptosis, cell cycle and invasion. Biomed Pharmacother. 2019 Aug;116:109004.

10. Nagappan H, Pee PP, Kee SHY, Ow JT, Yan SW, Chew LY, et al. Malaysian brown seaweeds Sargassum siliquosum and Sargassum polycystum : Low density lipoprotein (LDL) oxidation, angiotensin converting enzyme (ACE), $\alpha$-amylase, and $\alpha$-glucosidase inhibition activities. Food Res Int. 2017 Sep;99:950-8.

11. Amić A, Lučić B, Stepanić V, Marković Z, Marković S, Dimitrić Marković JM, et al. Free radical scavenging potency of quercetin catecholic colonic metabolites: Thermodynamics of $2 \mathrm{H}+/ 2 \mathrm{e}^{-}$ processes. Food Chem. 2017 Mar;218:144-51.

12. Barner-Kowollik C, Davis TP, Stenzel MH. Probing mechanistic features of conventional, catalytic and living free radical polymerizations using soft ionization mass spectrometric techniques. Polymer (Guildf). 2004 Oct;45(23):7791-805.

13. Onogi A, Naruse K, Sado T, Tsunemi T, Shigetomi $\mathrm{H}$, Noguchi $\mathrm{T}$, et al. Hypoxia inhibits invasion of extravillous trophoblast cells through reduction of matrix metalloproteinase (MMP)-2 activation in the early first trimester of human pregnancy. Placenta. 2011 Sep;32(9):665-70. 